\title{
CHARACTERIZATION OF COMPOSITE CONTAINING LDPE (LOW DENSITY POLY ETHYLENE) AND MODIFIED PINEAPPLE LEAF FIBER
}

\author{
Lestari Wardani ${ }^{1}$, Noerati ${ }^{1}$ and Doni Sugiyana ${ }^{2}$ \\ ${ }^{1}$ Politeknik STTT Bandung \\ Jalan Jakarta no 31, Bandung \\ ${ }^{2}$ Balai Besar Tekstil \\ Jl. Jendral Ahmad Yani 390, Bandung \\ E-mail: ureshii85@gmail.com
}

Received: 8 May $2020 \quad$ Revised: 20 July $2020 \quad$ Accepted: 23 July 2020

\begin{abstract}
CHARACTERIZATION OF COMPOSITE CONTAINING LDPE ( LOW DENSITY POLY ETHYLENE) AND MODIFIED PINEAPPLE LEAF FIBER. Pineapple leaf fiber could be used as a reinforcing material in natural fiber composites production with a synthetic polymer matrix. The typical problem in this process was the weak bond between the fiber component and the matrix. This study aimed to improve the bonds strength between pineapple leaf fibers and the polymer matrix of LDPE (Low Density Poly Ethylene) by modifying pineapple leaf fibers. The modification of pineapple leaf fibers was carried out through an enzymatic process using the xylanase enzyme. A modified fiber was then used as a fiber component in the composite using a commercial LDPE plastic matrix. Composites were made by the sandwich method using a hotpress machine at a temperature of $130^{\circ} \mathrm{C}$ for 10 minutes. The evaluation of the composites were carried out by testing the tensile strength properties using the Tensolab tool and thermal properties using the TGA (Thermal Gravimetry Analysis) instrument. The results of the mechanical properties test of the composite showed the modified pineapple leaf fiber-based composite had a better tensile strength (34.3 MPa) than the untreated pineapple leaf fiber-based composite (30.2 MPa). The results of the thermal properties test showed the decreasing of the mass occurred at temperature of $300-350^{\circ} \mathrm{C}$ due to degradation of the fiber,and it completely degraded at temperature of $450^{\circ} \mathrm{C}$.
\end{abstract}

Keywords: PALF, LDPE, Composite, Xylanase

\begin{abstract}
ABSTRAK
CHARACTERIZATION OF COMPOSITE CONTAINING LDPE ( LOW DENSITY POLY ETHYLENE) AND MODIFIED PINEAPPLE LEAF FIBER. Salah satu potensi pemanfaatan serat daun nanas adalah sebagai komponen penguat pada pembuatan komposit serat alam dengan matriks polimer sintetik. Permasalahan yang timbul pada saat pembuatan komposit berbasis serat alam adalah ikatan yang lemah antara komponen serat dengan matriksnya. Penelitian ini bertujuan untuk memperbaiki ikatan antara serat daun nanas dengan matriks polimer LDPE (Low Density Poly Ethylene) melalui modifikasi serat daun nanas. Modifikasi serat daun nanas dilakukan melalui proses enzimatik menggunakan enzim xylanase. Serat termodifikasi selanjutnya dijadikan komponen serat pada komposit menggunakan matriks plastik LDPE komersial. Pembuatan komposit dilakukan dengan metode sandwich menggunakan mesin hotpress pada suhu $130^{\circ} \mathrm{C}$ selama 10 menit. Evaluasi terhadap komposit dilakukan melalui pengujian sifat mekanik kekuatan tarik dan mulur menggunakan alat Tensolab dan pengujian sifat termal dengan menggunakan alat TGA(Thermal Gravimetry Analysis). Hasil uji sifat mekanik memperlihatkan bahwa komposit berbasis serat daun nanas hasil modifikasi memiliki kekuatan tarik lebih baik (34,3 MPa) dibandingkan dengan komposit berbasis serat daun nanas tanpa perlakuan (30,2 $\mathrm{MPa}$ ). Hasil uji sifat termal menunjukkan bahwa terdapat kombinasi nilai pada tahapan degradasi antara serat daun nanas hasil modifikasi dan LDPE. Pada suhu $300-350^{\circ} \mathrm{C}$ terdapat pengurangan berat akibat degradasi dari serat, kemudian terdegradasi sempurna pada suhu sekitar $450^{\circ} \mathrm{C}$.
\end{abstract}

Kata kunci: PALF, LDPE, Komposit, Xilanase 


\section{INTRODUCTION}

Nowadays, public awareness of degradable material material is increasing. It makes researchers use natural materials for their research. Currently, researchers have shown a wide interest in natural fibers for applications in composites [1]. There are many plant fibers available which has potential to be applied as raw materials for composites such as pineapple, jute, kenaf, ramie, bamboo, palm etc [2]-[7]. Pineapple leaf fiber (PALF) was chosen for the study because it is a waste product of pineapple cultivation and available without any additional cost input. As PALF is showing superior mechanical properties, it has potential as fiber reinforced composite [8]. In this research PALF is choosen as fiber reinforced composite. It is expected to make a composite with good mechanical properties from PALF as fiber reinforced composite and LDPE as the matrix.

PALF show lower degree of compatibility with hydrophobic polymers due to its hygroscopic nature. Existence of natural waxy substance on surface of fibre layer provide low surface tension, which does not allow a strong bond with polymer matrix. However, the literature suggests various methods to improve the fiber surface to make it suitable for good interfacial fibre/matrix bonding [9]. In this study, PALF treated with xylanase enzyme before it used as fiber reinforced composite.

PALF was choosen as fiber reinforced composite because it has a good mechanical properties. PALF was treated with xylanase enzyme to rough the surface of PALF. LDPE was choosen because it widely used but easily disposed as waste. Combining treated PALF and LDPE as a composite will obtain more valuable product.

Xylanase treatment will roughen the surface of PALF so it wil increase the compatibility level between the PALF and its matrix. Pretreatment was used to increase the work of xylanse enzyme in the surface of PALF.

The aim of this research is to improve compatibility level of PALF as composite by surface modification use enzyme treatment. The surface modification of pineapple leaf fibers was carried out using the xylanase enzyme. In this research, composites were made consisting of LDPE (Low Density Poly Ethylene) as the matrix and pineapple leaf fiber as composite reinforcement. The mechanical and thermal properties of the modified from pineapple leaf fiber composite were then characterized.

\section{EXPERIMENTAL METHOD}

\section{Materials and Equipments}

Pineapple leaf fibers were used is a modified pineapple leaf fiber from commercial pineapple leaf fiber. The age of the fibers was 1.5 years old. However, as long as the pineapple leaves reaches above $60 \mathrm{~cm}$, it can be used as fiber. The fiber was modified by using
Xylanase enzyme obtained from BPPT (Badan Pengkajian dan Penerapan Teknologi) Research and Development Indonesia. LDPE matrix used is from commercial LDPE (Low Density Poly Ethylene) plastic for wrap. Britton Robinson buffer solution was made using $\mathrm{H}_{3} \mathrm{BO}_{3}, \mathrm{NaOH}$, $\mathrm{H}_{3} \mathrm{PO}_{4}, \mathrm{CH}_{3} \mathrm{COOH}$ technical grade.

Main equiptment used in this study were assembled hotpress machine with power 2200 watts, machine dimensions $(64 \times 80 \times 65) \mathrm{cm}$, upper heater size $(30.5 \times 30.5) \mathrm{cm}$, bottom heater size $(40.5 \times 40.5)$, heater temperature scale $(25-220)^{\circ} \mathrm{C}$, hydraulic pump pressure scale 0-700 bar (10,000 psi). Experiment done at Politechnic STTT Bandung, and Center for Textile (BBT) Bandung.Method and Procedure

Pineapple leaf fiber was modified using xylanase enzyme after pretreatment. The pretreatment was done using $\mathrm{Na}_{2} \mathrm{CO}_{3}(2 \mathrm{~g} / \mathrm{L})$ and teepol $(2 \mathrm{~g} / \mathrm{L})$ solution. Pretreatment was followed by rinsing several times, one with hot water, rinsing and drying under ambient conditions. Pineapple leaf fiber was subjected to xylanase enzyme ( $8 \mathrm{wt} \%$ with respect to the fiber) for one hour under $70^{\circ} \mathrm{C}$ in Britton Robinson buffer solution. The enzyme treatment was carried out at 1:40 liquor ratio. Enzyme treatment finished with rinsing several times, one with hot solution (contains $1 \mathrm{~g} / \mathrm{L} \mathrm{Teepol}^{\mathrm{TM}} 610 \mathrm{~S}$, a mixture surfactant) and drying under ambient conditions.

Pineapple leaf fiber were cut to a length of 200 $\mathrm{mm}$, which has same with the window frame $(200 \times 200$ $\mathrm{mm}^{2}$ ). The method used in this experiment based on Miah experiment on Jute fiber with several modification [4]. Composite were made using pineapple leaf fiber by sandwich method. Composite were obtained by placed the pineapple leaf fiber between the LDPE plastic. Composite was arranged in a window frame of $200 \times 200$ $\mathrm{mm}^{2}$. Composite was made using hotpress machine with $135^{\circ} \mathrm{C}, 25 \mathrm{psi}$ for 10 minutes. The ration between fiber and LDPE matrix is 25:75. There are two variation of the fibers used as reinforce composites, the were raw and modified pineapple leaf fiber.

\section{Characterization}

Characterization of the LDPE sample was carried out using FTIR Spectrophotometer (Thermo scientific USA, Nicolet iS 5 iD 5 ATR). Characterization of the PALF and composite samples were carried out using FTIR Spectrophotometer (Prestige 21 Shimadzu). The spectra are recorded in the mid infrared region of $4000-400 \mathrm{~cm}$ 1 in the absorption mode.

Mechanical properties of the composite was using Mesdan Tensolab-5000 code 2515. Preparation of tensile specimens LDPE and its composites were cut to form type I tensile specimens according to ASTM D638. Composite samples tested for tensile strength and elongation percentage. Composite morpology was carried out using Mesdan lab video analyser stereo microscope code 250F. Thermal Gravimetry Analysis 
(TGA) was carried out using TGA instrument (Thermal Analysis System Type STA7300 Hitachi).

\section{RESULT AND DISCUSSION}

\section{LDPE Characterization ( Low Density Poly Ethylene)}

LDPE used in this research was LDPE from plastic wrap so it needs to characterized for conforming its polymer type. FTIR result from LDPE sample are presented in Figure 1. Peak appears at $2915,51 \mathrm{~cm}^{-1}$ and $2847,8 \mathrm{~cm}^{-1}$ corresponds to $\mathrm{CH}_{2}$ group, and peak at 1462,52 and $1471,647 \mathrm{~cm}^{-1}$ come from C-H bond. Another peak appears at 729,69 $\mathrm{cm}^{-1}$ show $\mathrm{H}-\mathrm{C}-\mathrm{H}$ group. Those peaks correspond with characteristic of LDPE reported in literature [10].

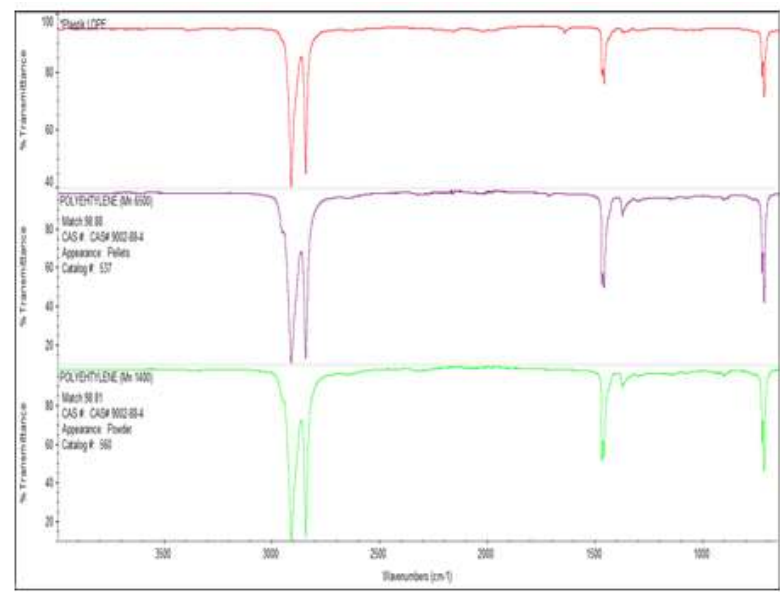

Figure 1. FTIR Spectrum of used LDPE and polyethylene as compator. Red line is FTIR result of the used matrix (LDPE plastic); purple line is FTIR result of polyethylene pelets and the green line is FTIR result of polyethylene powder.
FTIR result of LDPE presented the similar peak with PE (Poly Ethylene) peak refference. This result indicated that the tested polymer matrix is PE (Poly Ethylene).

\section{Morphology of Composites}

Composites results show in Figure 2. The morphology of raw PALF and LDPE composite was showing the base color of the raw PALF. The impurities of the fiber is clearly visible and the fiber in the composite show a rigid fiber. The morphology of PALF (with xylanase treatment) and LDPE composite was showing a whiter color compared to raw PALF. Impurities are less than the composite in raw PALF. The morphology of PALF (with $\mathrm{Na}_{2} \mathrm{CO}_{3}$ pretreatment and xylanase treatment) and LDPE composite was showing a whiter color than raw PALF. Impurities are less than the composite in raw PALF and the rigidity of the PALF is reduced.

\section{Composite Characterization}

\section{FTIR Characterization}

FTIR result among LDPE, pineapple leaf fiber and composite show at Figure 3. FTIR result in Figure 3 presented that there is no new group formed at the composite. This result indicates that there is no chemical bond between pineapple leaf fibers and LDPE. The bonding between pineapple leaf fibers and LDPE was occured possibly through the interfacial adhesion between pineapple leaf fibers and LDPE.

\section{Tensile Strength}

Tensile strength of composites shown in Figure 4.
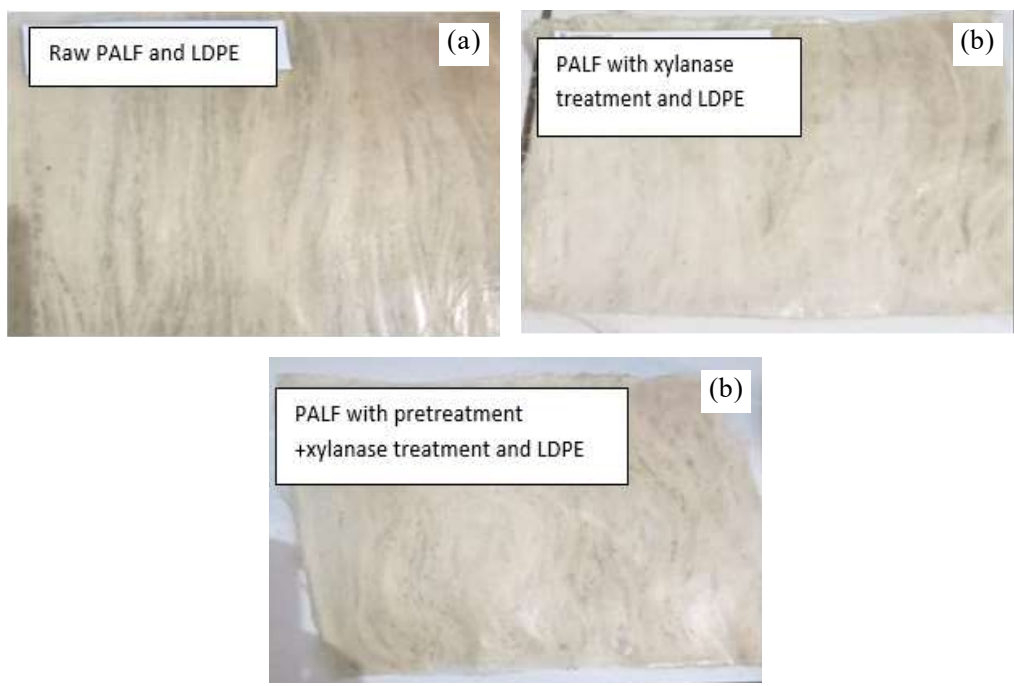

Figure 2. PALF composites (a) raw PALF+LDPE (b) PALF with xylanase treatment + LDPE; (c) PALF with pretreatment + xylanase treatment + LDPE. 


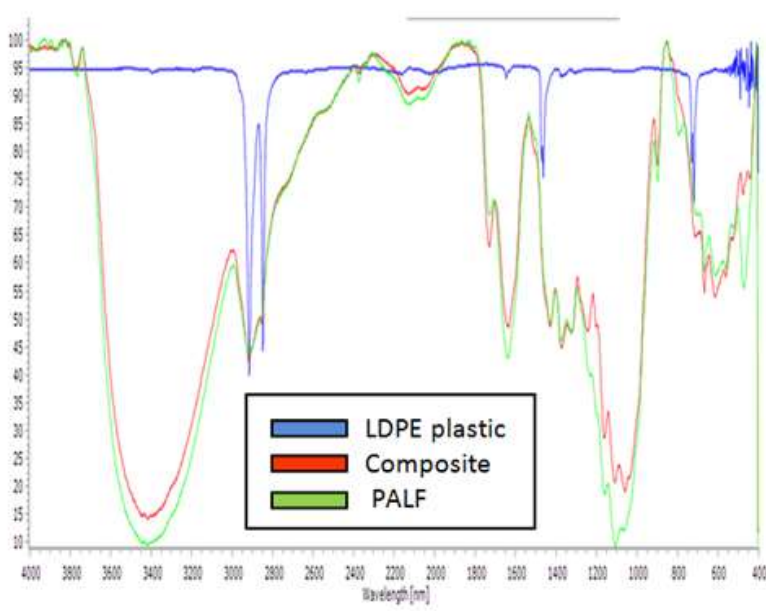

Figure 3. FTIR result among LDPE, pineapple leaf fiber and composite.

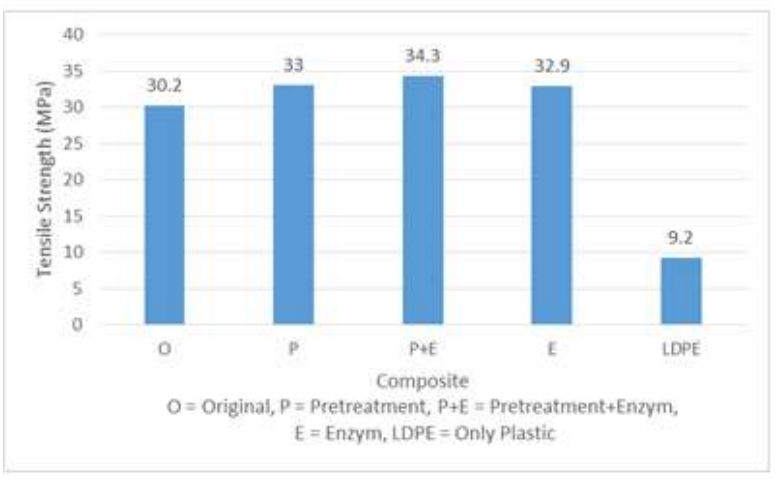

Figure 4. Tensile strength of composites.

Results of the composite tensile strength test showed that the tensile strength of the LDPE matrix composites reinforced by pineapple leaf fibers increased when compared to the tensile strength of $100 \%$ LDPE matrix. From figure 4 , it can be seen that the greatest tensile strength value is found in pineapple fiber with pretreatment and enzymes(1), followed by pretreatment only(2), then enzymes(3) then pineapple leaf fiber without treatment (original) (4) and $\operatorname{LDPE}(5)$.

The rough surface enhanced the interfacial interaction between the hydrophilic surface of the fiber and the hydrophobic polymer matrix. Therefore, this possibly explained an increase of tensile strength of the composites when the fiber content was increased. [11]. Interfacial adhesion between the fiber and the matrix can cause stresses are easily transferred from matrix to fiber and the mechanical properties including tensile, flexural and impact strength are improved [12].

The surface of the fiber which becomes rough increases the interfacial interaction between the hydrophilic surface of the fiber and the hydrophobic polymer matrix resulting in an increase in the tensile strength of the composite [11].

\section{Percentage Elongation at Break}

Percentage elongation at break of composites shown in Figure 5.

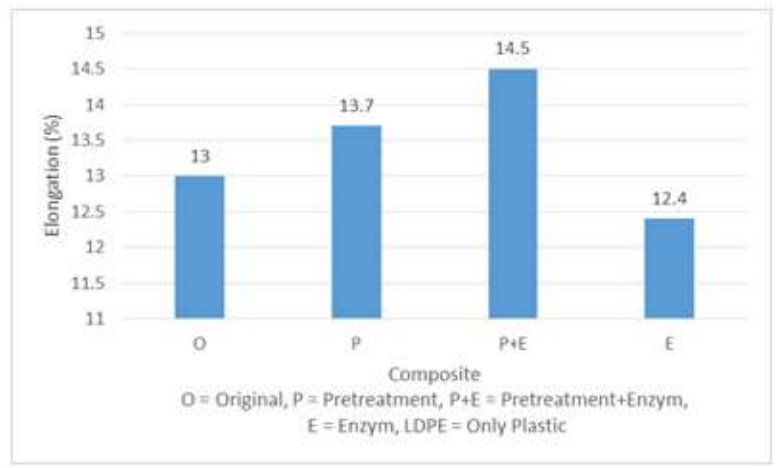

Figure 5. Percentage elongation at break of composites.

The results of the composite tensile strength test showed that the percentage elongation value of the LDPE matrix composites reinforced by pineapple leaf fiber decreased when compared to $100 \%$ LDPE matrix. The largest percentage elongation value is found in the $100 \%$ LDPE matrix about $856.08 \%$. The addition of pineapple leaf fiber as a composite reinforcement caused a decrease in the percentage elongation value. We can consider that fiber to be totally brittle and matrix phase to be reasonably ductile. A fiber reinforced composite consisting of the fiber and matrix material will exhibit the uniaxial stressstrain response [13]. The elongation decreased with increasing the PALF content for thermoplastic, interpreting that the composites became stiff and brittle upon fiber loading. .

\section{Modulus Elasticity}

Modulus elasticity of composite shown at Table 1. The modulus of elasticity is defined as the slope of the stress-strain curve $(\sigma-)$ in the elastic deformation region [14].

Table 1. Modulus Elasticity of Composite

\begin{tabular}{lc}
\hline \multicolumn{1}{c}{ Sample } & $\begin{array}{c}\text { Modulus Elasticity } \\
(\mathrm{MPa})\end{array}$ \\
\hline Plastic (LDPE) & 57.973 \\
Raw PALF (O) & 233.197 \\
PALF +enzyme (E) & 242.927 \\
PALF + Pre+Enzim (P+E) & 314.708 \\
\hline
\end{tabular}

The value of the stress-strain relationship of LDPE composites and pineapple leaf fiber is different as shown in Table IV.1. The modulus of elasticity of pure LDPE shows flexible and resilient behavior with very high percentage elongation values while low modulus and tensile strength. The addition of pineapple leaf fiber increased the elastic modulus of the composite system 
to become more brittle. These results indicate that pineapple leaf fibers improve the mechanical properties of the composites [11]. The addition of pineapple leaf fiber increased the tensile strength of the composite.

The modulus of elasticity of the composites that had been treated with enzymes and pretreatment + enzymes had a higher value than the composite fiber from pineapple leaves without treatment. A large modulus of elasticity indicates increased stiffness in the composite. The higher stiffness of the composite with pretreatment + enzyme treatment indicated a stronger bond between the pineapple leaf fibers and the matrix. A strong bond indicates the compatibility level between matrix and fiber of the composite with treatment is higher than the composite without any treatment.

\section{Microscopic Characterization}

The composites were viewed in cross section form using a video analyzer with a magnification of 189x. Microscopic characterization results using a video analyzer are shown in Figure 6.

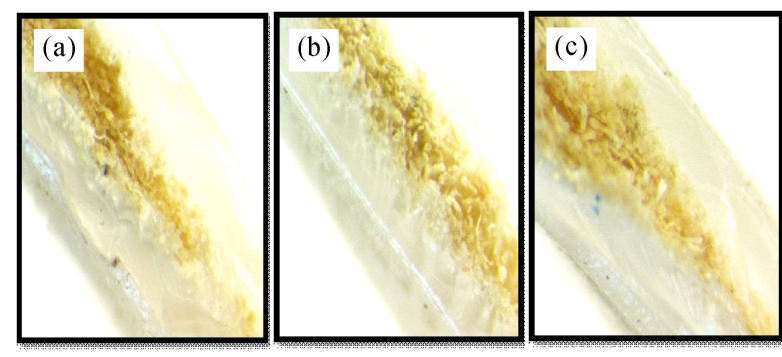

Figure 6. Cross section form of composites with 189x magnification (a) raw PALF+LDPE (b) PALF with xylanase treatment+ LDPE; (c) PALF with pretreatment + xylanase treatment + LDPE.

The pineapple leaf fiber composites video analyzer shows the interaction between pineapple leaf fibers and LDPE, which is shown by the adhesion that occurs between pineapple leaf fibers and LDPE. Surface adhesion can be seen from the area of fibers attached to the matrix.

\section{Thermal Property}

Thermogravimetric analysis (TGA) curve of pineapple leaf fibers at a temperature of $60^{\circ} \mathrm{C}$ to $100^{\circ} \mathrm{C}$ showed a weight reduction due to dehydration. The degradation of pineapple leaf fiber occurs in two stages. In the first stage, degradation ranging from $250^{\circ} \mathrm{C}$ to $300^{\circ} \mathrm{C}$ and about $7 \%$ weight reduction of pineapple leaf fiber probably corresponds to the thermal degradation of lignin and dehydrocellulose. In the second stage which is the main peak, the maximum degradation temperature is about $320-360^{\circ} \mathrm{C}$ with the biggest weight reduction. This weight reduction is related to the thermal degradation of dehydrocellulose [11].

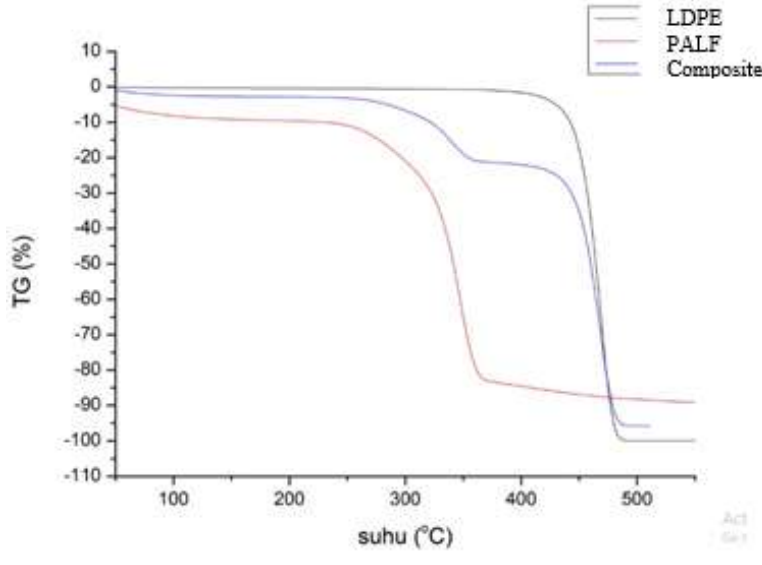

Figure 7. TGA Curves of PALF, LDPE and Composite.

The thermal stage which indicates the degradation of lignin, hemicellulose and pectin is the most important stage in the TGA testing of pineapple leaf fiber. The temperature at this stage can be used to analyze the thermal stability of pineapple leaf fibers. Thermogravimetric analysis (TGA) on pineapple leaf fibers showed that pineapple leaf fiber has more stable thermal fiber properties and a higher working temperature limit [15]. Pineapple leaf fiber has a greater OOT (Onset Oxidation Temperature) value than other fibers. OOT is defined as the maximum working temperature of each fiber bundle before reaching a significant level of degradation [16]. OOT can be identified as an important part of the TGA curve. The OOT value of pineapple leaf fiber which is greater than other fibers indicates that pineapple leaf fiber has good mechanical properties. Therefore pineapple leaf fibers can be used as reinforcing fibers in composites, depending on the polymer used [15].

Thermogravimetric analysis curve on LDPE shows a one-stage degradation curve between $450-500^{\circ} \mathrm{C}$ [17]. The graph is in line with the research of Satlewal et al. Which states that the thermal degradation of pure LDPE starts at $376^{\circ} \mathrm{C}$ and the total degradation of weight loss starts at $466^{\circ} \mathrm{C}[17]$.

The TGA graph on the pineapple leaf fiber and LDPE composites shows a combination of the degradation stage between the pineapple leaf fiber and the LDPE degradation stage. At temperatures of 300-350 there is a reduction in mass due to fiber degradation, then it is completely degraded at a temperature of around 450 . There are two peaks of weight loss indicating the absence of chemical bonds between PALF and LDPE.

The TGA graph of pineapple leaf fiber and LDPE can be used as a reference in determining the right temperature in the process of making composites [11]. The temperature of the pineapple leaf fiber composite and LDPE should not exceed the degradation value of pineapple leaf fiber and LDPE. 


\section{CONCLUSION}

. The pineapple fiber treated with Pretratment $(\mathrm{P})$, enzymes $(\mathrm{E})$ and pretreatment + enzyme $(\mathrm{P}+\mathrm{E})$ increased the performance of the tensile strength of the composite with $\mathrm{P}+\mathrm{E}$ treatment is the highest value of tensile strength (34.3 Mpa). This result showed that enzymatic treatment combine with pre-treatment $(\mathrm{P}+\mathrm{E})$ can improve the compatibility level between PALF and LDPE as composite. The results that have been obtained indicate that the use of the xylanase enzyme is more environmentally friendly when compared to using a strong alkaline such as $\mathrm{NaOH}$ for the same purpose.

\section{ACKNOWLEDGMENT}

The authors would like to appreciate The Departement of Textile Chemistry Polytechnic STTT Bandung, The Department of Textile Engineering, Politechnic STTT Bandung, Center for Textile (BBT) Bandung and Center for Bio industrial Technology, Deputy for Agro-Industry and Biotechnology Technology (BPPT) for their contribution and support.

\section{REFERENCES}

[1] N. Jaramillo, D. Hoyos, and J. F. Santa, "Composites with pineapple-leaf fibers manufactured by layered compression molding Compuestos de fibra de hoja de piña fabricados mediante," vol. 18, No. 2, no. July 2016, pp. 151-162, 2017.

[2] D. Shanmugam and M. Thiruchitrambalam, "Static and dynamic mechanical properties of alkali treated unidirectional continuous Palmyra Palm Leaf Stalk Fiber / jute fiber reinforced hybrid polyester composites," J. Mater., vol. 50, pp. 533-542, 2013.

[3] G. O. Glória et al., "Tensile strength of polyester composites reinforced with PALF," J. Mater. Res. Technol., vol. 6, no. 4, pp. 401-405, Oct. 2017.

[4] M. J. Miah, M. A. Khan, and R. A. Khan, "Fabrication and Characterization of Jute Fiber Reinforced Low Density Polyethylene Based Composites: Effects of Chemical TreatmentMiah, M. J., Khan, M. A. dan Khan, R. A. (2011) "Fabrication and Characterization of Jute Fiber Reinforced Low Density Polyet," J. Sci. Res., vol. 3, no. 2, pp. 249-259, Apr. 2011.

[5] H. M. Akil, M. F. Omar, A. A. M. Mazuki, S. Safiee, Z. A. M. Ishak, and A. A. Bakar, "Kenaf fiber reinforced composites/ : A review Kenaf fiber reinforced composites/ : A review," Mater. Des., vol. 32, no. 8-9, pp. 4107-4121, 2011.
[6] Y. Chen, L. Sun, O. Chiparus, I. Negulescu, V. Yachmenev, and M. Warnock, "Kenaf/ramie composite for automotive headliner," J. Polym. Environ., vol. 13, no. 2, pp. 107-114, 2005.

[7] A. Majumdar, "Modelling of thermal conductivity of knitted fabrics made of cotton-bamboo yarns using artificial neural network," J. Text. Inst., vol. 102, no. 9, pp. 752-762, 2011.

[8] S. Mishra, M. Misra, S. S. Tripathy, S. K. Nayak, and A. K. Mohanty, "Journal of Reinforced Plastics and Reinforcement in PALF-Polyester Composite/ : Surface Modification and Mechanical Performance," 2001.

[9] L. U. Devi, K. Joseph, K. C. M. Nair, and S. Thomas, "Ageing Studies of Pineapple Leaf Fiber Reinforced Polyester Composites," 2004.

[10] A. . Setiawan and F Aulia, "Blending of LowDensity Polyethylene and Poly- Lactic Acid with Maleic Anhydride as A Compatibilizer for Better Environmentally Food- Packaging Material Blending of Low-Density Polyethylene and PolyLactic Acid with Maleic Anhydride as A Compatibilizer fo," 2017.

[11] R. Chollakup, R. Tantatherdtam, S. Ujjin, and K. Sriroth, "Pineapple Leaf Fiber Reinforced Thermoplastic Composites/ : Effects of Fiber Length and Fiber Content on Their Characteristics," 2010.

[12] W. Liu, M. Misra, P. Askeland, L. T. Drzal, and A. K. Mohanty, “'Green' composites from soy based plastic and pineapple leaf fiber: fabrication and properties evaluation," Polymer (Guildf)., vol. 46, no. 8, pp. 2710-2721, Mar. 2005.

[13] Wi. Callister and D. G. Rethwisch, "Material Science and Engineering an Introduction," 2010.

[14] I. Galobardes, S. H. Cavalaro, A. Aguado, and T. Garcia, "Estimation of the modulus of elasticity for sprayed concrete," Constr. Build. Mater., vol. 53, pp. 48-58, 2014.

[15] M. Jawaid, M. Asim, and P. M. Tahir, Pineapple Leaf Fibers. Springer Nature Singapore, 2020.

[16] A. R. S. Neto et al., "Comparative study of 12 pineapple leaf fiber varieties for use as mechanical reinforcement in polymer composites," Ind. Crop. Prod., vol. 64, pp. 68-78, 2015.

[17] A. Satlewal, R. Soni, M. Zaidi, Y. Shouche, and R. Goel, "Comparative Biodegradation of HDPE and LDPE Using an Indigenously Developed Microbial Consortium," vol. 18, pp. 477-482, 2008. 